\title{
Are Peat and Sawdust Truly Improve Quality of Briquettes as Fuel Alternative?
}

\author{
Andi Bustan ${ }^{1} \&$ Muhammad Arsyad ${ }^{2}$ \\ ${ }^{1}$ Faculty of Education, Palangkaraya University, Central Kalimantan, Indonesia \\ ${ }^{2}$ Department of Agricultural Socio-economics, Faculty of Agriculture, Hasanuddin University, Makassar, South \\ Sulawesi, Indonesia \\ Correspondence: Andi Bustan, Faculty of Education, Palangkaraya University, Central Kalimantan, 73111, \\ Indonesia. Tel: 62-822-5511-3782. E-mail: abustan@fkip.upr.ac.id
}

Received: May 17, 2017

doi:10.5539/jsd.v10n5p61
Accepted: July 28, $2017 \quad$ Online Published: September 29, 2017

URL: https://doi.org/10.5539/jsd.v10n5p61

\begin{abstract}
The availability of energy and fuel is always a critical issue, and currently the increasing scarcity and price of kerosene is causing problems for both households and businesses. For example, chicken farmers in Central Kalimantan need to maintain the room temperature when nursing chicks up to 12 days old, and currently have few alternatives to kerosene stoves. Non-carbonized briquettes made from a mix of peat and sawdust can provide an alternative fuel source. The sawdust is available from local sawmills, which is otherwise an unutilized waste product that is burnt off, so adding to local smoke pollution. This study was conducted to determine the optimal composition and manufacturing process to produce bricks that have a maximal calorific content whilst maintaining a long burning time and a reduced tendency to break. Analyses in the laboratory showed that the highest calorific content obtainable was $19020.63 \mathrm{~kJ} / \mathrm{kg}$ with a peat/sawdust ratio of 2:1 (20 kg of peat and 10 $\mathrm{kg}$ of sawdust). These briquettes had a production efficiency of $83.26 \%$, and calculations showed the overall production cost of the finished product to be around $40 \%$ lower than that of kerosene. The results indicate that a peat soil and sawdust mix produce a briquette that is viable as a fuel alternative, and based on this the researcher recommends that it be further developed commercially to meet the additional energy demands at lower cost of people in rural areas and industrial sectors.
\end{abstract}

Keywords: briquette, fuel alternative, peat soil, sawdust

\section{Introduction}

The world is faced with huge problems in fossil fuel shortages nowadays. Some developed countries start in long debate of new energy demand due to nuclear energy that still take a risk in utilization, while in developing countries are still trying to tackle the energy needs and preference new energy resources beside fossil fuel that were much decreased in decades. However, by the rapid climate change, people need to start to develop more ecofriendly in renewable energy resources as an action in sustainable development. Looking at closely to the people of Central Kalimantan suffer from a scarcity of fossil fuels, especially kerosene, which is used for household purposes such cooking, boiling water and other necessities. Without kerosene housewives, especially those living in rural areas, have trouble carrying out everyday activities in the kitchen. Concerned by the lack of kerosene in the market, the government has provided gas stoves along with a good sized gas cylinders of $3 \mathrm{~kg}$ and $12 \mathrm{~kg}$ that have been circulated widely throughout Indonesia. The scheme however did not work due to many people being scared news reports of exploding gas cylinders and resulting casualties. It is clear then that this problem requires solutions that are appropriate and safe for use in the kitchen. The natural resources are abundant, especially in Central Kalimantan where the peat fields are completely untouched and can to be processed into a substitute energy source to kerosene, which is becoming ever more scarce in the market. The energy content of peat, if processed properly, can be used as an alternative fuel, formed of briquettes to meet the needs of housewives.

Twidell, J., \& Weir, T. (2006) said that the material of plants and animals, including their wastes and residues, is called biomass. It is organic, carbon-based, material that reacts with oxygen in combustion and natural metabolic processes to release heat. And the peatland areas in Indonesia covers $10 \%$ of the total land area, or about 20 million ha. According Wahyunto (2011) the peatlands in Kalimantan, based on the results of remote sensing 
technology and information systems is 4777905 ha, whilst Central Kalimantan has 2659234 ha of peatlands (55.64\% of the total Kalimantan). The carbon stored in the peat is 10 times higher than the calorific value of carbon stored in the soil minerals causing the peat to be a good base material briquettes. Carbon stored on the surface consists of biomass and nekromas, while carbon below the surface (in the ground) is stored in the form of peat bog, the roots of plants, and microbes.

Jaenicke, J., et al. (2008) estimate that the total carbon stored in peatlands in Indonesia is around 55 Gigatonnes. This is based on calculations that peatland has a carbon content of at least $18 \%$ (dry weight basis) and a minimum thickness of $50 \mathrm{~cm}$. At various locations in the province of Jambi, Riau and Central Kalimantan, the thickness of the peat could reach 6-10 m and the carbon content of peat soil can reach $60 \%$. For each thickness of one meter, the peat store is around 400-800 $\mathrm{t}$ of carbon (C) per ha, or an average of about $600 \mathrm{t} \mathrm{Cha}^{-1} \mathrm{~m}^{-1}$. This means that the peat with a thickness of $5 \mathrm{~m}$ stores around $3000 \mathrm{t} \mathrm{Cha}^{-1}$. For the whole of Indonesia it is estimated that there around 37-55 Gt (gigatonnes) of carbon high $\mathrm{C}$ formed because of the water-saturated state (poor drainage) on land that was originally pile in the form of shallow lakes.

The chemical characteristics of the peat land in Indonesia is very diverse and determined by the mineral content, thickness, type of plant constituent of the peat and mineral species on the substratum (at the base of peat), and the degree of decomposition of peat. Peatlands in Sumatra and Kalimantan are generally dominated by woody material. Therefore, the composition of the organic material is largely lignin which generally exceed $60 \%$ of the dry matter, whilst the content of other components such as cellulose, hemicellulose, and protein generally does not exceed $11 \%$.

Processing of the peat into briquettes was not new to some communities in Indonesia, but was generally unknown to most people in the rural areas of Central Kalimantan. The use of briquettes for cooking in the home was still rare and very difficult to find. In some places, coal briquettes are only circulated in a limited market, that of used in chicken breeding and is used to raise the room temperature when raising chicks. These briquettes are made from coal instead of peat, which produces a smokey smell of kerosene and smoky. The result of field observations on the use of briquettes for heating in the chicken farms shows that heat generated by the briquettes is very hot. For household activities, emitting a smell of kerosene (the distinctive smell of coal briquettes) prevented people from using it for cooking or boiling water, since the scent permeated into food making it inedible.

The smell of briquettes from raw materials such peat can be reduced by mixing in the substance zeolite, which also reduces the smoke from the briquettes when they start burning. However, zeolite is difficult to find in market, therefore, the researchers tried to use a mix of sawdust to overcome the problem of kerosene smell and smoke, because sawdust, besides having a high calorific value is also having flammable. This condition accelerates the combustion process of briquettes. The sawdust with neem powder (organic adhesive) as binding agent has considerably increased the strength of the briquette with a little reduction in burning rate, has been carried out by Rajaseenivasan, T., et al (2016).

Sawdust is very easy to find in Central Kalimantan especially in Palangka Raya because in this area many centers sawmills, where waste sawdust is not fully utilized. The use of biomass fuel such as composite sawdust biquette has been proposed to be a good source of renewable energy for domestic cooking (Kuti, O. A. \& Adegoke, C. O., 2008). The use of sawdust briquettes was very well received by the target families, not only for the cost savings involved but also for the higher performance, ease of use and health care issues. Communication and awareness workshops played a very important awareness role in using sawdust briquettes as substitute for traditional fuel materials (Sanchez, E. A., 2014).

Researchers believe that the right combination of sawdust and peat, with the use of an adhesive that is easily found in the market, would lead to the easy production quality briquettes that produced less smell, less smoke and have a high calorific value. According to Tumutegyereize, P., et al. (2016), gross calorific values were comparable for the two fuel types (carbonized briquettes \& charcoal) in the range of $19523.05-27285.38 \mathrm{~kJ} / \mathrm{kg}$. Low calories in peat briquettes were, due to coal briquettes made from coal flakes that are no longer be marketed. Using good coal to make briquettes would be uneconomic in production, and in addition it was considered that the raw materials themselves are also difficult to obtain in this area. Employers tend to sell a chunk of coal that does not require processing but has a high resale value. Some calorific values of some types of fuel are classified as follows: 
Table 1. calorific values of various fuels (Adaptation from Parto, B., 2015)

\begin{tabular}{lll}
\hline \multirow{2}{*}{ Fuel } & \multicolumn{2}{l}{ Calorific values $(\mathrm{kJ} / \mathrm{kg})$} \\
\cline { 2 - 3 } & Lower & Higher \\
\hline Peat & 4186.80 & 6280.20 \\
Lignite & 12560.40 & 18840.60 \\
Sub-bituminous & 18840.60 & 27214.20 \\
\hline
\end{tabular}

The research used two types of adhesives separately. The adhesives used are starch and cement, both of which are believed to make more quality briquettes suitable for households and which do not easily broke in the mold. According to Lawton, J. W. (2014), starch is used in many industrial products and its function ranges from being an adhesive, binder, flocullent, filler, and fermentation ingredient to being a viscosity modifier. While cement is used to minimize cracking. This research use $12.5 \%$ binder composition adapted from Dalle, Y. (2003) research that $10-15 \%$ of binder used in peat briquettes production was resulting maximum high calorific value. The correct composition is required between the adhesive raw materials, peat and sawdust in order to produce briquettes with high calorific value, odorless, smokeless and which are not easily crushed or broken. The study was conducted to determine the ratio and composition of raw material briquette optimized to obtain a higher calorific value when used as an alternative fuel for activities such as cooking.

\section{Materials and Method}

\subsection{Materials}

Briquettes are a solid fuels alternative to fossil fuels that are made firstly through a non carbonation process, and then compressed either with or without a binder and other additives. In this study, four basic ingredients of peat briquettes were used; peat soil and sawdust as the main raw materials, and cement and starch as the adhesive glue. Producing briquettes out of a material is a way to get the desired shape and size so as to be suitable for a specific purpose, namely domestic use, and peat is suitable for processing in this way by using a mixture of peat and adhesive which is then taken through a drying process for the correct temperature and time.

\subsection{Method}

\subsubsection{Process Option}

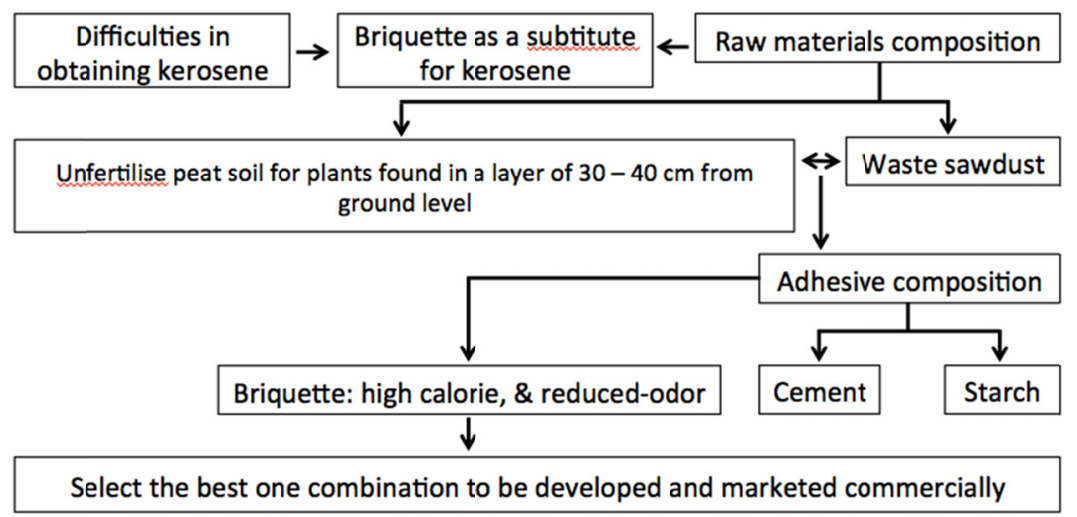

Figure 1. Theoretical framework

The peat and sawdust are not carbonized before being processed into briquettes. After crushing and mixing the raw materials, starch and cement are added to accelerate their compaction. The process is cheaper, and because the substance is produces a more complete combustion in which all volatile matter arising from the briquettes will be consumed by flames on the surface of the furnace. These briquettes are generally used for small industries. To develop briquettes using peat as the raw material requires two types of equipment, firstly equipment for producing the briquettes, such as pressing machine briquette, mixer, raw materials crusher, sieves, blowers etc, and secondly equipment to characterize the quality of the briquettes.

Briquettes have been produced and dried in order to obtain good quality results, the drying is done by combining the two systems, namely aerated using fan (blower) and or using direct sunlight. This meant that the water 
content in the briquettes was not more than $3 \%$. Having confirmed the briquettes to be dry, they were put in a plastic bag that had been labeled according to the ratio between peat and sawdust. Each bag was filled with $3 \mathrm{~kg}$ of briquettes and then subsequently packaged neatly in order to be sent to a laboratory. There are different samples in total:

Table 2. Samples in different composition of raw materials

\begin{tabular}{cccccc}
\hline No & Samples & Peat soil $(\mathrm{Kg})$ & Sawdust $(\mathrm{kg})$ & \multicolumn{2}{c}{ Binding material } \\
\cline { 5 - 6 } & & & 10 & 1.25 & 1.25 \\
\hline 1 & $(1: 1)$ & 10 & 10 & 2.50 & 1.25 \\
2 & $(2: 1)$ & 20 & 10 & 3.75 & 1.25 \\
3 & $(3: 1)$ & 30 & 20 & 1.25 & 2.50 \\
4 & $(1: 2)$ & 10 & 30 & 1.25 & 3.75 \\
5 & $(1: 3)$ & 10 & & & \\
\hline
\end{tabular}

\subsubsection{Data Analysis}

The calorific value of briquettes was determined by measuring the energy generated during the combustion of a one kilogram sample placed on a silica plate, and then inserted into the combustion bomb calorimeter. Combustion begins once the initial temperature is steady, and during the combustion process measurements are carried out continuously until the maximum temperature is reached. Measurement of calorific value is then calculated based on the amount of heat released and also using the equation:

$$
\begin{aligned}
& \Delta \mathrm{T}=\mathrm{T}_{2}-\mathrm{T}_{1} \\
& \mathrm{Nk}=\frac{W X \Delta T}{A}-\mathrm{B}
\end{aligned}
$$

Description:

$$
\begin{aligned}
& \mathrm{Nk}=\text { calorific value }(\mathrm{cal} / \text { gram }) \\
& \mathrm{W}=\text { calorific value }(\mathrm{kal}) \\
& \mathrm{T}_{1}=\text { Temperature at first }\left({ }^{\circ} \mathrm{C}\right) \\
& \mathrm{T}_{2}=\text { Temperature after burning }\left({ }^{\circ} \mathrm{C}\right) \\
& \mathrm{A}=\text { weight of sample burned } \\
& \mathrm{B}=\text { Correction hot on iron wire }(\mathrm{cal} / \mathrm{gram})
\end{aligned}
$$

The effectiveness of briquettes' production is expressed as a percent. While the calculations that can be used is, the ratio between production with raw materials processed amount of times one hundred percent. Production efficiencies obtained from raw materials with the results obtained are:

$$
\varepsilon=\frac{\Sigma \text { productivity }}{\Sigma \text { raw materials }} \times 100 \%
$$

Calculation of the efficiency factor is considered important since including one part that can contribute in determining the amount of capital on the basis of sales.

\section{Results}

\subsection{Raw Materials Selection}

\subsubsection{Peat}

In Kalimantan, peatland which is still dominated forest areas (mangrove, peat forest, forest plantation and bushes as amounts of 2402362 ha (49.9\%) and 1373563 ha (28.6\%) respectively. Peatland was used for agriculture these are: plantation, farmland (food and horticulture crops) and paddy field are as amounts of 298156 ha (6.2\%). 255835 ha (5.3\%) and 127781 ha (2.7\%) respectively. Peatland has been used for settlement as amounts of 20966 ha $(0.6 \%)$ (Wahyunto, Hidayat, A., \& Iskandar, A., 2010). The substances of this soil are carbon, hydrogen, nitrogen and oxygen that have important thing if utilize into chemical industrial and/or renewable energy resource. And as shown peatland was no fully utilized in energy resources while this soil can be a 
potensial alternative source of domestic or industrial energy to contribute to fuel crisis in Kalimantan. The south coastal area, peatland situated in the South Kalimantan and Central Kalimantan province, there are a vast peat among Sebangau (passing three districts, Palangka Raya, Pulang Pisau and Katingan), Kahayan, Kapuas and Barito rivers and its considered to have a high level of carbonization, and in the area being considered the highest are found in the District of Pulang Pisau and Kapuas ( $80 \mathrm{~km}$ to the south of Palangka Raya) where the thickness of the peat soil in these area can be around 1-5 meters. These districts was contained more peat than that in Palangka Raya where the composition peat:soil are around 60\%:40\% and are only 20\%:80\% in Palangka Raya (the research is conducted). Peat briquettes are manufactured from peat soil that exists on the surface with a depth of no more than 1 meter, here the level of water content tends to be less than the soil underneath, so that a much shorter drying time is required to achieve the $5 \%$ water content required. A water content in excess of $5 \%$ would allow a higher evaporation rate, so that the quality of the briquettes produced not in accordance with market expectations. Apart from the low water levels of the surface peat, soils in the area also have a higher wood powder content, as a result of weathering on its surface of trees up to hundreds of years ago. Therefore, at a certain dryness level the peat is easy to burn, especially when lit with a flame, something that is often utilized by the farmers wanting to clear the plantation in the dry season.

\subsubsection{Sawdust}

Sawdust is a waste product of the wood processing industry, and is uses as a raw material for making charcoal. Optimal utilization of sawdust in the mixture of briquettes is part of a strategic effort in the improvement and management of forest products. The addition of wood powder intended as accelerator startup, as the result of the burning of sawdust is to produce a zeolite compound which is able to absorb the smoke and smell produced during combustion of briquettes. Sawdust can also strengthen the bond in briquettes as it tends to fill the cavities that exist, and in addition there are also the many wood oxygenated functional groups that facilitate the process of combustion.

Sawdust has not previously been fully utilized despite it being a biomass with a relatively calorific value. Cellulose $(48.89 \%)$, lignin $(28.90 \%)$, water content (6.02\%), ash content $(2.09 \%)$, and pentosan $(14.10 \%)$ are contained in sawdust resulting high calorific value up to $15269.55 \mathrm{~kJ} / \mathrm{kg}$. If the sawdust and peat together (in addition to the starch and cement adhesive) are processed into briquettes they lead to a good quality renewable alternative energy source. Generally, most of the waste sawdust is only used as a furnace fuel or else burned off, which can itself cause environmental pollution. This is another reason of using sawdust as a mixture of peat soil in the manufacturing of briquettes.

The selection of the sawdust can be determined by visits to any of the furniture or sawmill timber companies in the company that have the types of hard high-quality wood (Ironwood, meranti, benuas, rubber, etc) which produces good quality of waste sawdust. The quality is determined in part by the dryness and particle size produced by sawmill. The tendency of the dust of this timber type is to absorb heat more readily than the soft woods or another timbers which produce a dust with fibers that are difficult to decompose and contain a high water content. High quality sawdust was relatively easy to find in furniture companies (wood processing plants) producing doors, frames, windows etc for use in households.

\subsubsection{Starch and Cement}

An organic binder (such as starch, tar, bitumen, starch, molasses and paraffin) produce relatively little ash after burning briquettes, and is generally an effective adhesive. Briquettes using starch in particular were noted to burn with little or no smoke. Using starch as an adhesive leads to briquettes with a low density, ash content, volatile content, but is higher in water content, bound carbon content and calorific value. Critically is that its use causes less smoke than almost any other material. A study has been accounted by Drobikova, K., et al. (2016) that preparation of the blast furnace sludge briquettes using starch as a binder and their thermal treatment represents a suitable method for recycling of this type of metallurgical waste. Moreover, the composition of the resulting gas is favourable for its use as a fuel. However, starch is not resistant to moisture and indeed tends to absorb water from the air, therefore, the levels of gluten in the briquettes should not be too high because it can lead to decreased quality of briquettes which can then increase the amount of smoke produced.

An inorganic binder can maintain the resilience of the briquettes during the combustion process so that the fuel's permeability is not disturbed, however the addition of ash originating from the binder can inhibit combustion and lead to a lower calorific value. Examples of inorganic binders include clay, sodium silicat and cement. Cement is a material that is adhesive and cohesive, and which allows attachment of mineral fragments into a solid mass. It also provides a lower combustion temperature with a longer burning time, since cement is a store of heat and unburnt, cement will absorb heat that is produced during the burning process and store it, so extending the 
burning time. This happens since, with an increasing amount of adhesive, the increasing levels of gluten, the greater compressive strength, the bonding between the particles will be stronger, causing greater resilience briquette press. Past research has shown that briquettes with cement adhesive have the highest compressive strength.

\subsection{Processing Briquette}

Peat briquettes were manufactured with the aim of making a comparison between different types of wood waste mixture with the peat soil. Peat soil was dried and separated from wood or other materials with drying being done by using either direct sunlight or else a blower. The level of dryness was expected to reach $95 \%$ by including sawdust as a mixture, since the water content contained in the feedstock should not exceed $5 \%$. The briquettes are subsequently weighed and sorted based on the peat-sawdust composition ratio. The results of this weighing is used to calculate to multiples of $10 \mathrm{~kg}$, for example, if the sample has a ratio o $2: 1$, then $20 \mathrm{~kg}$ of peat soil is mixed with $10 \mathrm{~kg}$ sawdust, thus the amount of raw materials used always follows a predefined ratio.

All the constituents are divided up into samples, peat and sawdust into $10 \mathrm{~kg}$ samples, and the cement and starch into $1.25 \mathrm{~kg}$. Starch and cement were first diluted simultaneously put in a heating furnace that has been provided up to the boiling point when bubbles appear, all the while, the mixture is stirred on that constituents of the adhesive are evenly distributed and have a high adhesive power. The raw material is then put into a mixer with a capacity of $50-100 \mathrm{~kg}$ for processing. This would be repeated five times, once for each composition ratio using the prepared samples. Within this mixing process, the adhesive would be added to produce uncracked and unbroken briquettes.

The required amounts peat soil and sawdust are put together into the mixer and the motor started. After the adhesive has been homogeneously mixed and boiled, this is also poured into a mixer, adding it to the other raw materials. Mixing continues for approximately 15 minutes, after which it is removed from the mixer in put into a briquette-making machine, and these are then dried for at least $3 \times 24$ hours using indirect sunlight or using a blower. Once dried the briquettes were separated and stored irrespective of quality and all samples were taken for further analysis of their calorific value.

The pressing process for briquettes (the first sample using with raw peat soil) takes approximately 25 minutes to obtain a good quality, and the results are then heated or dried by using a blower on board or carpet basking. The second sample (ratio 2:1) is created using the same steps in the sample above. In total five samples were prepared with varying compositions of the adhesive and the factors stirring in the mixer. The adhesive composition depended on the briquettes, for example if the ratio of raw material samples is $(1: 1)$ then the amount of adhesive cement and starch used was $1.25 \mathrm{~kg}$ each. For different ratios of raw materials, more adhesive was added in multiples of $1.25 \mathrm{~kg}$.

\subsection{Analysis of Production}

Table 3. Results of laboratory analysis for value calories

\begin{tabular}{|c|c|c|c|c|c|c|c|}
\hline \multirow[t]{2}{*}{ No } & \multirow[t]{2}{*}{ Sample Code } & \multicolumn{2}{|c|}{${ }^{1}$ Total Weight $(\mathrm{kg})^{-}$} & \multirow{2}{*}{$\begin{array}{c}{ }^{1} \text { Level of } \\
\text { Efficiency } \\
(\%)\end{array}$} & \multirow{2}{*}{$\begin{array}{c}\text { Sample } \\
\text { weight } \\
(\mathrm{kg})\end{array}$} & \multirow{2}{*}{$\begin{array}{l}\text { Top } \\
\text { Size } \\
(\mathrm{mm})\end{array}$} & \multirow{2}{*}{$\begin{array}{c}\stackrel{2}{\mathrm{GCV}} \\
\mathrm{kJ} / \mathrm{kg} \mathrm{adb}\end{array}$} \\
\hline & & $\begin{array}{l}\text { Raw material + } \\
\text { adhesive glues }\end{array}$ & Productivity & & & & \\
\hline 1 & Peat: Sawdust (1:1) & 22.5 & 19.25 & 85.56 & 2.07 & 31.5 & 11823.52 \\
\hline 2 & Peat : Sawdust (2:1) & 33.75 & 28.10 & 83.26 & 2.74 & 50 & 19020.63 \\
\hline 3 & Peat : Sawdust (3:1) & 45 & 35.90 & 79.78 & 3.82 & 50 & 16856.06 \\
\hline 4 & Peat : Sawdust (1:2) & 33.75 & 24.55 & 72.74 & 2.97 & 31.5 & 12212.90 \\
\hline 5 & Peat : Sawdust (1:3) & 45 & 34.60 & 76.89 & 3.65 & 31.5 & 13431.25 \\
\hline
\end{tabular}

The first sample with a ratio $1: 1$ (produced with $10 \mathrm{~kg}$ of peat $10 \mathrm{~kg}$ and $10 \mathrm{~kg}$ of sawdust) produced $19.25 \mathrm{~kg}$ of briquettes. With intact briquettes analysis showed that they produced $11823.52 \mathrm{~kJ} / \mathrm{kg}$. The size of the briquette when it reaches a maximum peak calorific value is $31.5 \mathrm{~mm}$. The second sample with a ratio $2: 1$ produced 28.10 $\mathrm{kg}$ of briquettes, and intact (no cracks) samples of these reached $19020.63 \mathrm{~kJ} / \mathrm{kg}$, briquettes of $50 \mathrm{~mm}$ giving the maximum calorific value. 


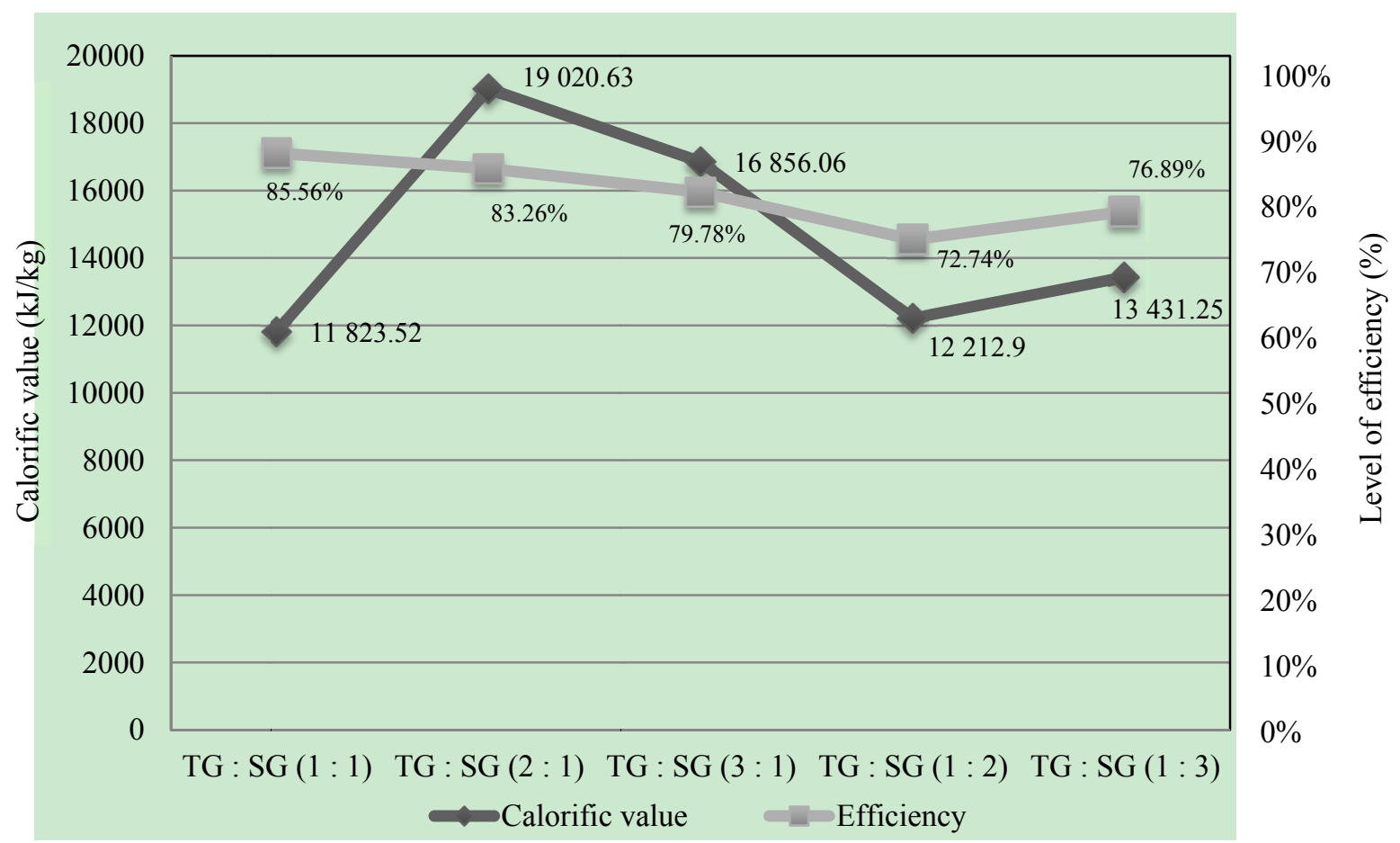

Figure 2. Composition of Raw Material Relationship Graph Briquettes Rated Calories and production efficiency

As clearly presented in Fig. 2, the composition ratio of 2:1 in the second sample showed the highest calorific value compared with the other four samples. This is because of the ratio $(20 \mathrm{~kg}$ of peat and $10 \mathrm{~kg}$ of sawdust) is most ideal composition for the carbon content of these materials. Sawdust is also undergoes carbonization, but if the sawdust is burned by itself (no other mix) it tends to burn faster to ashes. Conversely, old peat soil will burn slowly, and will remain long as coals becoming a new fire. By combining these two raw materials at a particular ratio can produces a higher calorific value and not to ashes. Another factor contributed to this ratio of 2:1 having the highest calorific content is getting the adhesive composition correct, as well as other elements, such as stirring, which produce quality briquettes that do not easily break or crack and have a longer burning time.

\subsection{Feasibility Mixture of Peat and Sawdust Briquettes as Fuel}

Calorific value is an important parameter because it affects fuel efficiency. The greater the calorific value, the amount of fuel required will be less. By this mean, fuel consumption will be more economical.

Table 4. Calorific value specification of graded wood materials briquettes

\begin{tabular}{cc}
\hline Grade & $\mathrm{kJ} / \mathrm{kg}$ \\
\hline $\mathrm{A}_{1}$ & $\geq 17499.99$ \\
$\mathrm{~A}_{2}$ & $\geq 17299.98$ \\
$\mathrm{~B}$ & $\geq 16800.00$
\end{tabular}

Source: adaptation from www.nrcan.gc.ca

Table 4 shown the standard of calorific value needed to producing briquettes in large scale. While the briquettes meet the requirement were sample 2 at $19020.63 \mathrm{~kJ} / \mathrm{kg}$ (grade A1) and sample 3 at $16856.06 \mathrm{~kJ} / \mathrm{kg}$ (grade B). Furthermore, sample $1(11823.52 \mathrm{~kJ} / \mathrm{kg})$, sample $4(12212.90 \mathrm{~kJ} / \mathrm{kg})$ and sample $5(13431.25 \mathrm{~kJ} / \mathrm{kg})$ were not recommended to produce more as fuel in the future. As data shown, the calorific value qualities of briquettes produced in this study are sufficient enough to produce the require heat for domestic activity such as cooking and also for industrial application especially chicken farms. 


\subsection{Effectiveness of Production: Using Pressing Machine}

Using briquette machines means utilizing all existing components in production efficiently, which means that many of the ingredients or raw materials as a whole can not be used briquettes, nothing is wasted, and nothing is stuck on the processing machine, and some have been destroyed or broken because of the movement molding machine. These conditions allow researchers to calculate the efficiency of processing products that are expressed as a percent. For the first sample with a ratio 1: $1,(10 \mathrm{~kg}$ of peat and $10 \mathrm{~kg}$ of sawdust) had a total of $20 \mathrm{~kg}$ of raw material, and produced $19.25 \mathrm{~kg}$ of briquettes of acceptable quality $(85.56 \%)$ followed by sample 2 $(83.26 \%)$, sample $3(79.78 \%)$, sample $4(72.74 \%)$, and sample $5(76.89 \%)$ respectively. Calculation of the efficiency factor is considered important since it can contribute in determining the amount of capital on the basis of sales for domestic and livestock consumption.

As persuasively depicted in Fig. 2, the results show that raw materials in the ratio 1:1 are more efficient compared to other samples. Several things that determine the production efficiency of briquettes, and these vary in every samples, such as: (1) the stirring process to evenly mixed the glue to form variant briquettes depends on the time of stirring and how to use mixer, (2) The same adhesive composition for different compositions of the raw materials can be better or worse, (3) and also the number of chunks of raw material attached/left on the pressing machine varies by composition. This could definitely be a concern when the briquettes will be mass-produced for efficiency in terms of both marketing and quality.

\section{Discussion}

The composition of the sawdust more than that peat is proved to be less efficient when it produced on a large scale (sample 1:2 and sample 1:3). This was due to some factors: (1) the size of the sawdust was still quite big, (2) the water content was still high, and (3) the sawdust was a mixture of several types of wood. Furthermore, data shown the calorific value of briquettes was higher if it compared to coal/biomass briquettes production that normally can reach up to $19523.05 \mathrm{~kJ} / \mathrm{kg}$ (Adaptation from Tumutegyereize, P., et al, 2016). In this case, high calorific value of briquette that was not even higher than that was due to cement composition ratio given much in briquetting. Cement has a strong resistance but inhibit the combustion process ongoing, whereas if using starch as a whole in processing briquette leads to less efficient. In Central Kalimantan, starch was rarely used as an adhesive because it was difficult to obtain in the market and the price was relatively higher than that cement.

On the other hand, starch as an adhesive in the briquettes' manufacture is common practiced in small industry. However, as an economic factor and sometimes difficult to obtain in market, cement was combined with starch as adhesive glue. Cement chosen with consideration more easily available and cheaper, while in this term it could reduce production cost up to $40 \%$ if it compared to use starch as a whole in briquetting. As an illustration, briquettes with starch as an adhesive reach cost IDR 675/kg (1 USD = 13340 IDR) in production value (all includes 2 workers' salary, raw material, electricity, etc.), and if it combined with starch and cement cost IDR $450 / \mathrm{kg}$. By the term of production effectiveness, sales value in $1 \mathrm{~kg}$ briquette production cost reaches IDR $450 / \mathrm{kg}$, and the market sale price reached IDR $800 / \mathrm{kg}$, it can be said that in every $\mathrm{kg}$ of briquettes sold earned a profit of IDR $350 / \mathrm{kg}$. Based on sample 2 resulting $28.10 \mathrm{~kg}$ and in once production with machine capacity of 50 $\mathrm{kg}$ (1.5 times compositions) that work 8 hours/day and can operate three times in hour, so it would reach 42.15 $\mathrm{kg} \times 3 \times 8 \times$ IDR 350/kg = IDR 354060 .

The average length of time of use for one kilogram of briquettes if lit continuously can reach 3 hours and 23 minutes. While the average of domestic use is around 10 hours in a day, household was about $2.5 \mathrm{~kg}$ in needs and relocated cost IDR 2700/day and/or IDR 81 000/month.

\section{Conclusion}

Peat soil mixed with sawdust and then packaged in the form of briquettes can be used as an alternative fuel wood and kerosene, both in the household and also livestock production (particularly for the raising of young poultry in age of 1-12 days). Analysis of the calorie content showed that highest was obtained with the second of the five samples which was made with a peat/sawdust ration of $2: 1$, and which reached $19020.63 \mathrm{~kJ} / \mathrm{kg}$. The test batch used $20 \mathrm{~kg}$ of peat soil and $10 \mathrm{~kg}$ of sawdust, and also an adhesive ratio of 2:1. The most efficient of the production processes was found with the first sample (1:1 raw material composition) at $85.56 \%$, however this sample also had the lowest calorific value of $11823.52 \mathrm{~kJ} / \mathrm{kg}$. Size comparison covers the basic material of $10 \mathrm{~kg}$ of peat soil and sawdust of also $10 \mathrm{~kg}$. From these results, it can be concluded that the peat soil can be combined with sawdust in the manufacture of briquettes. And these can be made to meet the additional energy demands of inhabitants in rural areas and industrial sectors. With successful production of briquettes from peat soil and sawdust, people can have an alternative to fuel kerosene as sources of energy at lower cost. All these indicate that peat soil and sawdust truly improve quality and price of briquette as fuel alternative. 


\section{Acknowledgments}

This project was financially suported by University of Palangkaraya. The authors also wish to thank other participants involve in the project, local people and students of University of Palangkaraya for their cooperating in collecting and analyzing our data.

\section{References}

Dalle, Y. (2003). Optimization of Value Calories Briquette Peat as Alternative Fuel (Unpublished master's thesis). Hasanuddin University, Makassar, Indonesia.

Dariah, A., Susanti, E., \& Agus, F. (2011). Deposits and Carbon Emissions $\mathrm{CO}_{2}$ of Peat. Journal of Soil Research Institute. The Center for Agricultural Land Resources Research and Development Agency for Research and Development of the Ministry of Agriculture

Drobíková, K. (2016). Recycling of Blast Furnace Sludge by Briquetting with Starch Binder: Waste Gas from Thermal Treatment Utilizable as a Fuel. Journal of Waste Management, 48, 471-47. https://doi.org/10.1016/j.wasman.2015.11.047

Hakizimana, J. D. K., \& Kim, H. T. (2016). Peat briquette as an alternative to cooking fuel: A techno-economic viability assessment in Rwanda. Journal of Energy, 102, 453-464. https://doi.org/10.1016/j.energy.2016.02.073

Jaenicke, J., Rieley, J. O., Mott, C., Kimman, P., \& Siegert, F. (2008). Determination of the Amount of Carbon Stored in Indonesian Peatlands. Journal of Geoderma, 147, 151-158. https://doi.org/10.1016/j.geoderma.2008.08.008

Kuti, O. A., \& Adegoke, C. O. (2008). Comparative performance of composite sawdust briquette with kerosene fuel under domestic energy cooking conditions. AU Journal of Technology, 12(1), 57-61. Retrieved from http://www.journal.au.edu/au_techno/2008/jul08/journal121_article08.pdf

Lawton, J. W. (2014). Starch: Uses of Native Starch. Encyclopedia of Food Grains J. (2nd ed., Vol. 3). Pages 274-281.

Parto, B. (2016). Efficiency Studies of Combination Tube Boilers. Alexandria Engineering Journal, 55, 193-202. http://doi.org/10.1016/j.aej.2015.12.007

Rajaseenivasan, T., Srinivasan, V., Qadir, G. S. M., \& Srithar, K. (2016). An Investigation on the Performance of Sawdust Briquette Blending with Neem Powder. Alexandria Engineering Journal, 55(3), 2833-2838. https://doi.org/10.1016/j.aej.2016.07.009

Research Team. (2008). Research Potential of Coal Briquette in the Ketepung Village District of Kebonagung Pacitan. Board of Research, Development, and Statistics Pacitan, Indonesia.

Richards, S. R. (1990). Briquetting peat and peat-coal mixtures. Journal of Fuel Processing Technology, 25(3), 175-190. https://doi.org/10.1016/0378-3820(90)90025-N

Sanchez, E. A. (2014). Development of Briquettes from Waste Wood (Sawdust) for Use in Low-income Households in Piura, Peru. Proceedings of the World Congress on Engineering 2014 Vol II, WCE 2014, July 2 - 4, 2014, London, U.K. Retrieved from http://www.iaeng.org/publication/WCE2014/WCE2014_pp986-991.pdf

Sukandarrumidi. (2009). Engineering Peat, Briquette Coal and Organic Waste. Enterprises Utilizing Natural Resources marginalized. Gajah Mada University Press, Yogyakarta, Indonesia.

Sulistyono. Briquettes from Peat with Powdered Wood and its Possibility as an Alternative Energy. Forum of Science and Technology, 13(3), 54-61. Scientific Publications Gazette PUSDIKLAT MIGAS.

Tjahjono, E. J. A. (2006). Study Potential Sediment Peat in Indonesia Based on Environmental Aspects. In Proceeding: The results Exposure and Non Fields Field Activity. Geological Resources Center, Indonesia.

Tumutegyereize, P., Mungenyi, R., Ketlegetswe, C., \& Gandure, J. (2016). A comparative performance analysis of carbonized briquettes and charcoal fuels in Kampala-urban, Uganda. Energy for Sustainable Development J., 31, 91-96. https://doi.org/10.1016/j.esd.2016.01.001

Twidell, J., \& Weir, T. (2006). Renewable Energy Resources (2nd ed.). Taylor \& Francis e-Library.

Wahyunto, H. A., \& Iskandar, A. (2010). Characteristics of Peatland Location Demplot ICCTF province of Riau, Jambi, Central Kalimantan and South Kalimantan. Indonesian Center for Agricultural Land Resources Research and Development, Bogor, Indonesia. 
Wahyunto, N. K., Ritung, S., \& Sulaeman, R. (2011). Indonesian Peatland Map: Method, Certainty, And Uses. Indonesian Center for Agricultural Land Resources Research and Development, Bogor, Indonesia.

Wahyunto, R., S., Suparto, \& Subagjo. (2004). Distribution of Peat and Carbon content results in Sumatra and Kalimantan. Project Climate Change, Forests and Peatlands in Indonesia. Wetlands International Indonesia Programme and Wildlife Habitat Canada. Bogor, Indonesia.

\section{Copyrights}

Copyright for this article is retained by the author(s), with first publication rights granted to the journal.

This is an open-access article distributed under the terms and conditions of the Creative Commons Attribution license (http://creativecommons.org/licenses/by/4.0/). 